\title{
Papain-mediated reduction of MTT is an artifact but not an indicator of cell apoptosis in Saccharomyces cerevisiae
}

\author{
Shafaque Asif ${ }^{1}$, Gurjeet Kaur ${ }^{1}$, Usha Pendurthi ${ }^{2}$, Vineet Awasthi ${ }^{1 *}$ \\ ${ }^{1}$ Amity Institute of Biotechnology, Amity University Uttar Pradesh, Lucknow campus, Lucknow, 226028, India. \\ ${ }^{2}$ Department of Cellular and Molecular Biology, The University of Texas Health Science Centre at Tyler, Tyler, Texas, USA.
}

\begin{tabular}{l}
\hline ARTICLE INFO \\
\hline Received on: 04/06/2019 \\
Accepted on: 25/07/2019 \\
Available online: 01/09/2019 \\
\\
\hline Key words: \\
MTT, TPMET, papain, \\
apoptosis, plasma membrane.
\end{tabular}

\begin{abstract}
Papain is a proteolytic enzyme of the cysteine protease family used for tissue dissociation and cell separation. Papain's nonspecific proteolysis of the plasma membrane enzymes plays a crucial role in the homeostasis by disrupting the intracellular $\mathrm{pH}$ of the affected cells which might lead to cell death. When the Saccharomyces cerevisiae cells were treated with different concentrations of papain $(1.0,5.0,10.0,20.0$, and $30.0 \mu \mathrm{g} / \mathrm{ml}$ ), we found no alteration in the trans-plasma membrane electron transport (TPMET) activity and the intracellular $\mathrm{pH}$ of the cells, while it significantly decreased the mitochondrial dehydrogenase activity when measured by 3-(4,5-Dimethylthiazol-2-yl)2,5-Diphenyltetrazolium Bromide (MTT) assay. Additional verification of cell viability by trypan blue assay showed $98 \%-99 \%$ cell viability, contrary to the higher cell death observed with MTT assay. To better understand the decrease in cell viability with MTT assay, we tested the cell-free system that demonstrated a significant decrease of MTT concentration but the trypan blue assay showed more number of viable cells. This study shows that papain interferes with the MTT assay.
\end{abstract}

\section{INTRODUCTION}

Papain is a well-known proteolytic enzyme isolated from the latex of papaya (Carica papaya). Extensive studies have delineated the role of papain in the biological functions on the cell of many living organisms (Tsuge et al., 1999). It shows proteolytic activity on short-chain peptides, amino acids, esters, and amide linkages (Turk et al., 1996; Uhlig, 1998). It cleaves peptide bonds involving basic amino acids, which alter the homeostasis of cells (Halim et al., 2012). Papain demonstrated anti-cancer properties on the liver cancer cell line, HepG2 (Akila et al., 2014). It also suppressed the angiogenic activation of human umbilical vein endothelial cells (Mohr and Desser, 2013) and the Chymopapain showed cytotoxicity on mouse hepatoma cell line (Xiaoling et al., 2004).

MTT assay can lead to incorrect assessment of alcoholinduced cytotoxicity on primary glioblastoma cells (Jo et al., 2015)

\footnotetext{
"Corresponding Author

Vineet Awasthi, Amity Institute of Biotechnology,

Amity University Uttar Pradesh, Lucknow campus, Lucknow, 226028,

India.E-mail: vawasthi@lko.amity.edu
}

and interference of Resazurin (Neufeld et al., 2018). The high concentration of ethanol-induced damage and altered intracellular concentration of Nicotinamide adenine dinucleotide (NADH) in primary cells enhanced the nonspecific reduction of tetrazolium salt. For the assessment of cell viability, the cellular function such as enzyme activity, cell permeability, ATP production, and proton extrusion involves the movement of electron transport via transplasma membrane electron transport (TPMET).

TPMET is found nearly in every living cell including bacteria, yeasts, plants, and animals. It is associated with several cell metabolisms (Savini et al., 2010). The intracellular NADH/ $\mathrm{NAD}+$ plays a major role in cell proliferation and growth which is altered by cell membrane receptors. In the mammalian cells, TPMET functions as an alternate pathway to oxidize NADH and maintains the intracellular NADH/NAD+ dependent glycolytic production. TPMET is reported to be functional in the growth and proliferation of cancer cells which rely on the glycolytic pathway for energy production (Herst and Berridge, 2006; 2007).

MTT Assay is a widely used assay to measure cell proliferation and cytotoxicity (Berridge and Tan, 1993; Kaur et al., 2007; Vistica et al., 1991; Xiaoling et al., 2004). The live cells take 
up the yellow tetrazolium salt MTT [3-(4,5-Dimethylthiazol-2yl)-2,5-Diphenyltetrazolium Bromide)] inside the cell and convert it into purple-colored formazan crystals by the mitochondrial dehydrogenase enzyme. Several studies showed that not only mitochondrial dehydrogenase but also many intracellular reductases affect this reaction (Berridge and Tan, 1993; Cookson et al., 1995). On the other hand, intracellular NADH acts as the main electron donor in MTT reduction (Berridge and Tan, 1993; Kaur et al., 2007); therefore, the alteration of NADH is expected to affect the MTT assay.

According to Mohr and Desser, prolong incubation with papain significantly decreased the MTT assay without affecting the lactate dehydrogenase release from the human umbilical vein endothelial cells (HUVEC) (Mohr and Desser, 2013). The mechanism behind it remains unclear. To explore these results, we designed our experiments for nonspecific cytotoxicity of papain on the $S$. cerevisiae, a eukaryotic model organism.

\section{MATERIALS AND METHODS}

\section{Materials}

Saccharomyces cerevisiae (NCIM 3078) was purchased from the National Collection of Industrial Microorganisms, India. Malt extract, Bactopeptone, Glucose, Yeast extract, Papain, Trypan Blue, and Sodium Dodecyl Sulfate (SDS) were purchased from Himedia laboratories and Dimethyl sulfoxide (DMSO) from Amresco. 2',7'-Bis-(2-Carboxyethyl)-5-(and-6)Carboxyfluorescein, Acetoxymethyl Ester (BCECF, AM) and 3-(4,5-Dimethylthiazol-2-yl)-2,5-Diphenyltetrazolium Bromide) MTT, from Sigma Aldrich.

\section{Cell culture}

The yeast cells, $S$. cerevisiae (NCIM 3078), were cultured in the medium containing malt extract $(0.3 \%)$, bactopeptone $(0.5 \%)$, glucose $(1.0 \%)$, and yeast extract $(0.3 \%)$ for 24 hours at $30^{\circ} \mathrm{C}$.

\section{MTT assay}

The cells were treated in presence and absence of papain $(1.0,5.0,10.0,20.0$, and $30.0 \mu \mathrm{g} / \mathrm{ml})$ for 30 minutes. After the papain treatment, the $400 \mu \mathrm{l}$ cells were equally divided into two tubes labeled-A1 and B1. The A series of tubes were mixed with $10 \mu \mathrm{l} \mathrm{MTT}$ and the B tubes were washed with $1 \mathrm{ml}$ of $1 \mathrm{mM}$ Potassium phosphate buffer $\mathrm{pH}$ 6.6. The B series cells were then re-suspended in $200 \mu \mathrm{l}$ of phosphate buffer before adding $10 \mu \mathrm{l}$ MTT per well. Both A and B series of tubes were incubated for 1 hour at $37^{\circ} \mathrm{C}$ in incubator (GeNei). The cells were centrifuged at $1000 \times \mathrm{g}$ for 5 minutes. To each cell pellet, $150 \mu \mathrm{l}$ of solubilization buffer $(10 \%$ SDS in $0.01 \mathrm{~N} \mathrm{HCl} \mathrm{containing} 50 \mu \mathrm{l}$ DMSO) was added and left for 15 minutes. The cells were then centrifuged at $1000 \times \mathrm{g}$ for 5 minutes. The Optical Density (OD) of the supernatant at $570 \mathrm{~nm}$ was recorded with the spectrophotometer (UV 1800, SHIMADZU)

\section{Trypan blue assay}

The cells $200 \mu \mathrm{l} /$ well were plated at the density of $\mathrm{OD}_{600 \mathrm{~nm}}=1.0$. The cells were treated in the presence and absence of papain at different concentrations $(1.0,5.0,10.0,20.0$, and 30.0 $\mu \mathrm{g} / \mathrm{ml}$ ) for 30 minutes. The cells were then washed with $1 \mathrm{mM}$ Potassium phosphate buffer $\mathrm{pH} 6.6$ and stained with $0.4 \%$ trypan blue at the room temperature to determine the viability of the cells. A $10 \mu \mathrm{l}$ of the cell sample was loaded on the hemocytometer to count viable cells under the light microscope (OPTIKA).

\section{Scanning electron microscopy (SEM)}

The cells $(1,000 \mu \mathrm{l})$ were treated with different concentrations of papain $(1.0,5.0,10.0,20.0$, and $30.0 \mu \mathrm{g} / \mathrm{ml})$ for 30 minutes. After the treatment, the cells were washed with $1 \mathrm{mM}$ potassium phosphate buffer $\mathrm{pH}$ 7.0. The cells were fixed with $2.5 \%$ glutaraldehyde for 4 hours at $4^{\circ} \mathrm{C}$, washed with $0.1 \mathrm{M}$ Phosphate buffer $(\mathrm{pH}=7.0)$ for three times, and dehydrated with a gradient concentration of acetone $(30 \%-100 \%)$ for 15 minutes each. The pellet was placed on the aluminum stubs using carbon adhesive tape and was coated with gold-palladium using Ion Sputter Coater (JFC 1600, JEOL, Tokyo, Japan) at $20 \mathrm{~mA}$. The sample was viewed under the scanning electron microscope (JSM 6490 LV, JEOL, Tokyo, Japan) (Fischer et al., 2012).

\section{Transplasma membrane electron transport}

The rate of transplasma membrane transport was monitored by measuring the rate of ferricyanide reduction in the exogenous medium in the absence and presence of different concentrations of papain in a time-dependent manner (Revis and Misra, 1988). The change in OD was recorded at $420 \mathrm{~nm}$. Parallel control containing no cells was measured simultaneously. A millimolar extinction coefficient value of 1.0 for ferricyanide was used for calculation.

\section{Measurement of Intracellular pH}

The cells were placed at the $20 \mu \mathrm{M} \mathrm{BCECF-AM}$ at $30^{\circ} \mathrm{C}$ for 30 minutes on a rocking platform. After the incubation, cells were washed with $1 \mathrm{mM}$ potassium phosphate buffer $\mathrm{pH} 6.6$ and centrifuged at $1000 \times \mathrm{g}$ for 5 minutes. The pellet was suspended in the same buffer in the presence of different concentrations (1.0, $5.0,10.0,20.0$, and $30.0 \mu \mathrm{g} / \mathrm{ml}$ ) of papain for 30 minutes. After 30 minutes, the fluorescence was measured at excitation wavelengths $450 \mathrm{~nm}$ and $490 \mathrm{~nm}$, both with emission wavelength of $535 \mathrm{~nm}$ in a multimode reader (Varioskan flash) following slight modification in the method of Diakov et al. ( 2013).

\section{RESULTS AND DISCUSSION}

\section{Effect of papain on the rate of TPMET}

Transplasma membrane electron transport is present in unicellular eukaryotes, plants, and animal cells and is vital for growth and proliferation of cancer cells that rely on the glycolytic pathway for energy production (Driska et al., 1999; Mohr and Desser, 2013). Papain which is commonly used in cell isolation is more efficient and causes less damage to the tissue (Driska et al., 1999; Kinoshita et al., 2003; Mohr and Desser, 2013). It affects cytochrome c reductase activity of the $\mathrm{b}_{-} \mathrm{c}_{1}$ complex (Lorusso et al., 1989) which inhibits the reductase activity but our data did not show a significant effect on the TPMET activity (Fig. 1). 


\section{Measurement of intracellular pH}

Hydrogen ions are very important in yeast cell physiology as any variation in the $\mathrm{pH}$ will affect the enzymatic activity. The coupling of electron and proton transfer is recognized as a universal principle for modulating the intracellular $\mathrm{pH}$ homeostasis in the yeast $S$. cerevisiae. Our results did not show any significant change in the $\mathrm{pH}$ at different concentrations of papain (Fig. 2).

\section{Effect of papain on MTT assay}

Initially, a significant decrease in MTT activity with the increasing concentration of papain was observed. It appears that papain is inhibiting the cell viability which is similar to the previously published data (Mohr and Desser, 2013). This leads to

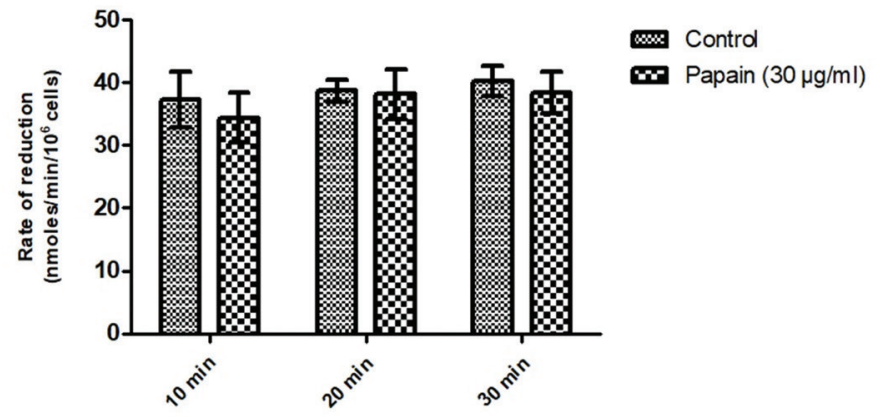

Figure 1. TPMET activity in control and papain $(30 \mu \mathrm{g} / \mathrm{ml})$ treated S. cerevisiae cells were measured at indicated time points. Data presented are mean \pm SD $(n=3)$.

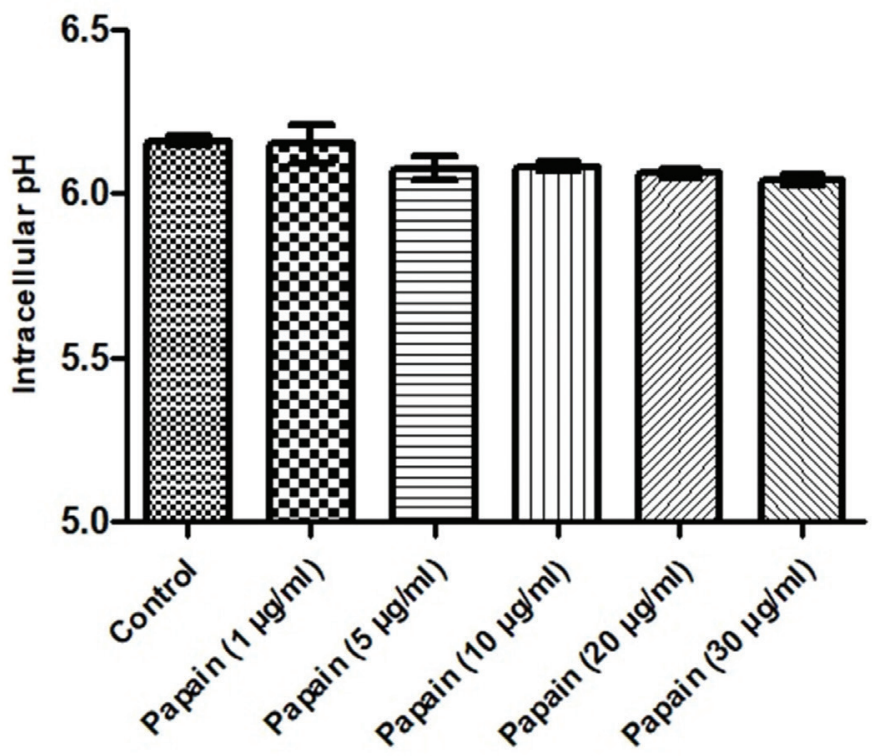

Figure 2. After 30 minutes incubation with BCECF-AM $(20 \mu \mathrm{M})$ the yeast cells were washed with $1 \mathrm{mM}$ phosphate buffer $\mathrm{pH} 6.6$ and treated with different concentrations of papain and measured the Intracellular $\mathrm{pH}$ by using excitation at 450 and $490 \mathrm{~nm}$ and emission at $535 \mathrm{~nm}$ in S. cerevisiae cells. Data presented are mean $\pm \mathrm{SD}(n=3)$. the assumption that the mitochondrial dehydrogenase activity may be affected; therefore, a decrease in cell viability was indicated. On the contrary, $98 \%-99 \%$ viability of the cells was observed using the trypan blue (Fig. 4). To further investigate this problem, we redesigned our experiment for MTT assay with washed and unwashed cells after the treatment of papain. The cells washed with $1 \mathrm{mM}$ Phosphate buffer $\mathrm{pH} 6.6$ almost resumed the absorbance equivalent to control cells (Fig. 3).

\section{Effect of papain on trypan blue method}

To further rule out this problem, the cell viability was checked by the trypan blue method which showed 98\%-99\% viability. No change of shape and size of the cells was observed with different concentrations of papain when visualized under a light microscope. The live and dead cells were manually counted and calculated to a percent value (Fig. 4).

\section{Scanning electron microscopy}

The SEM images (Fig. 5) of untreated control (A) and papain $(30 \mu \mathrm{g} / \mathrm{ml})(\mathrm{B})$ treated cells show viability. Both the cells show no ultrastructural changes which inferences for no cell death by papain.

\section{Interaction between papain and MTT}

The findings observed so far directed to study the MTT interaction in the presence and absence of papain without the cells (Fig. 6). We observed the gradual change in yellow color with the change in papain concentrations. A significant decrease in the absorbance at $420 \mathrm{~nm}$ was observed. This indicated that the MTT was dissociated in the presence of papain and not because of the cellular activity. It was assumed that the MTT did not move inside the cells for mitochondrial dehydrogenase activity to take place. The MTT assay was thus misleading, indicating decreased cell viability.

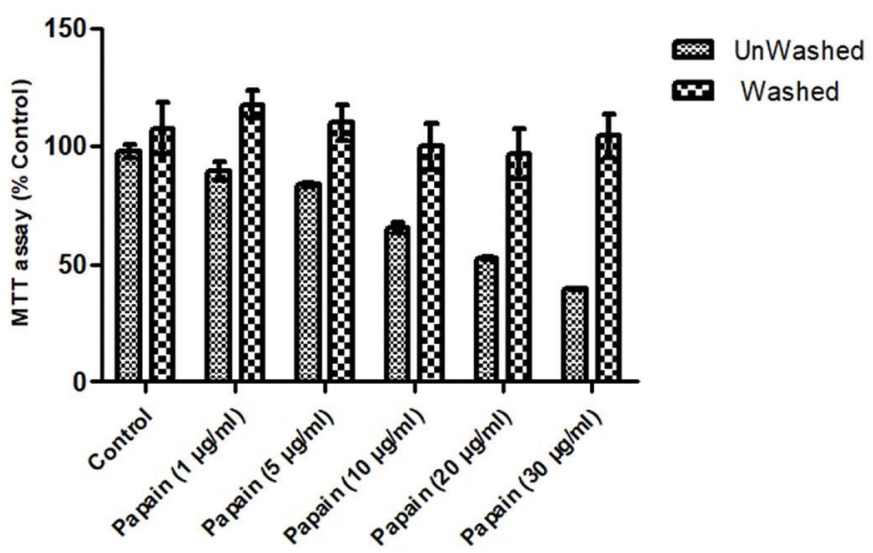

Figure 3. MTT assay in unwashed and washed $S$. cerevisiae cells after papain treatment for 30 minutes. The dotted bars denote the cells washed by $1.0 \mathrm{mM}$ Phosphate buffer, pH 6.6 and the dashed bars depict the unwashed cells. Data presented are mean $\pm \mathrm{SD}(n=3)$. 


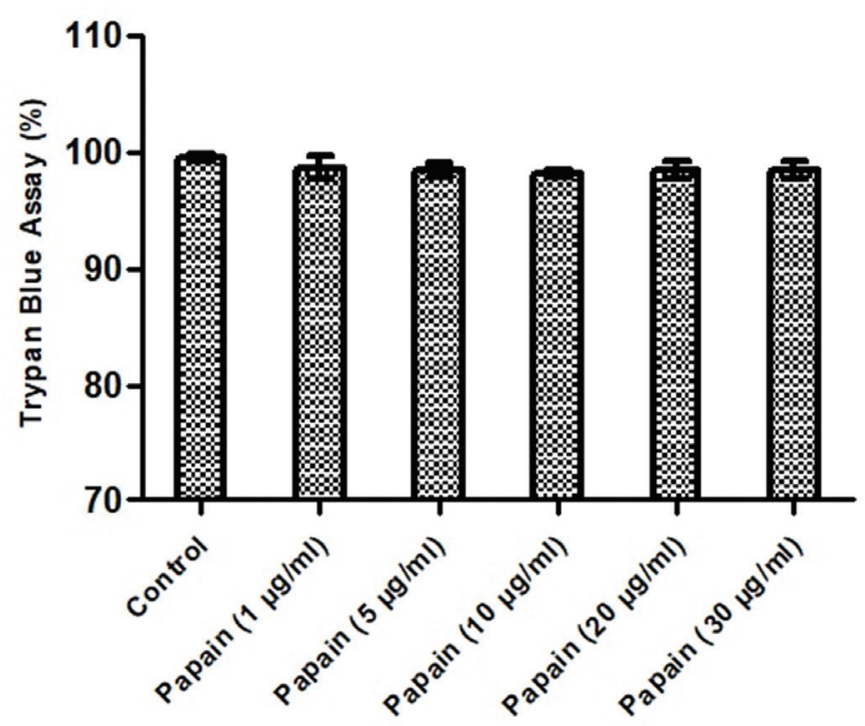

Figure 4. Trypan blue exclusion test in $S$. cerevisiae after the treatment with different concentrations of papain for 30 minutes. Data presented are mean \pm $\mathrm{SD}(n=3)$.

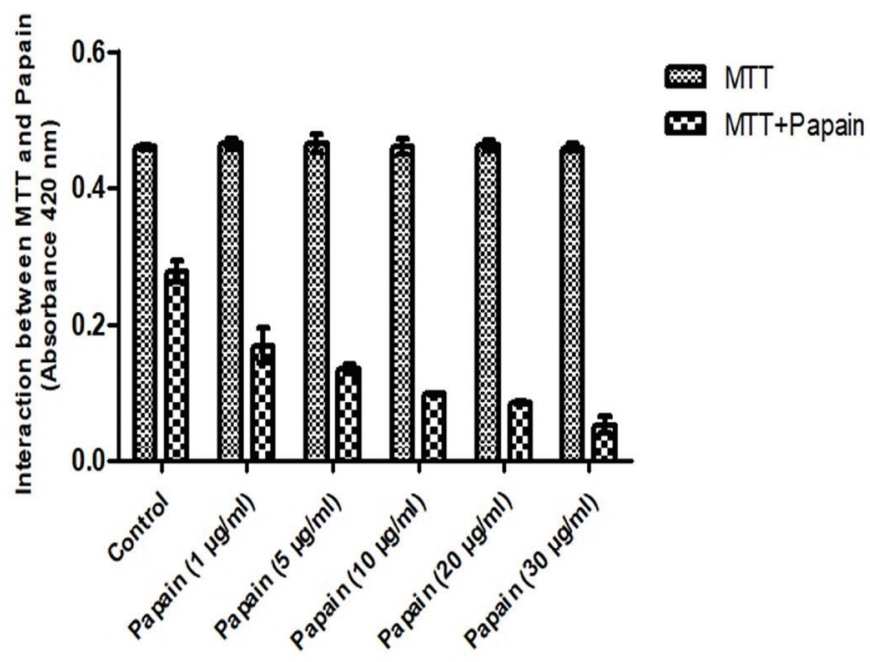

Figure 6. MTT assay depicting the interaction of papain with MTT in a cell free system. The dashed bars represent the absorbance of MTT without papain and the dotted bars depict the absorbance of MTT in the presence of different concentrations of papain for 30 minutes. Data presented are mean $\pm \mathrm{SD}$ $(n=3)$.
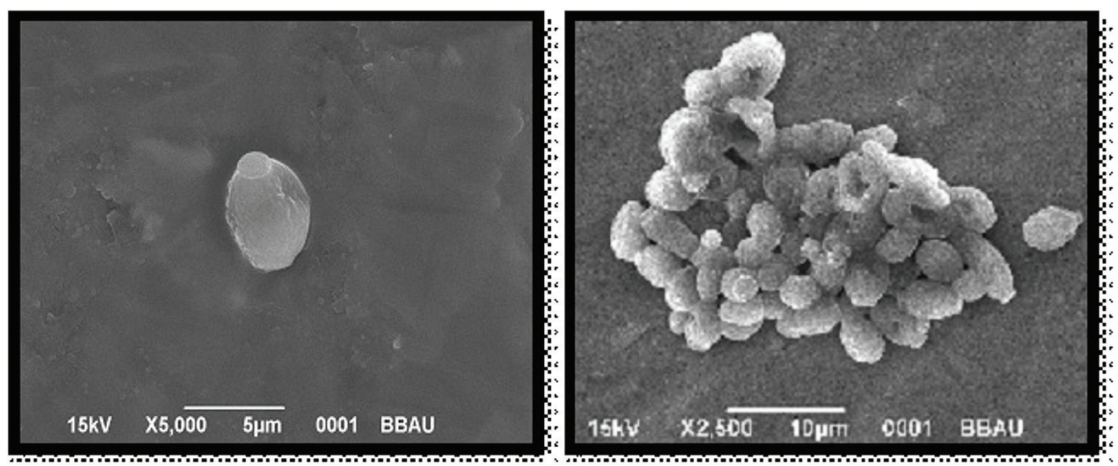

(A) Control

(1) Single Control cell

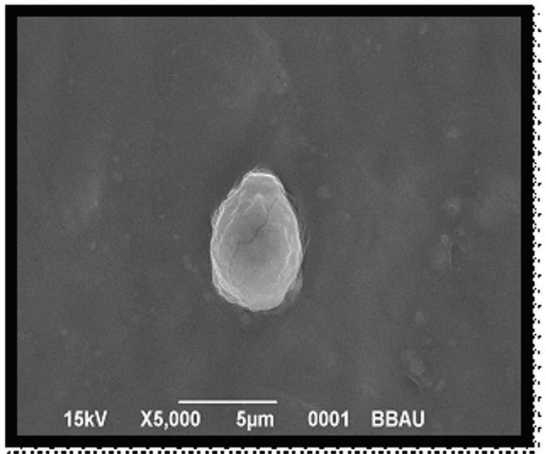

(B) Papain $(30 \mu \mathrm{g} / \mathrm{ml})$

(1) Single Papain $(30 \mu \mathrm{g} / \mathrm{ml})$ treated cell
(2) Grouped control cells

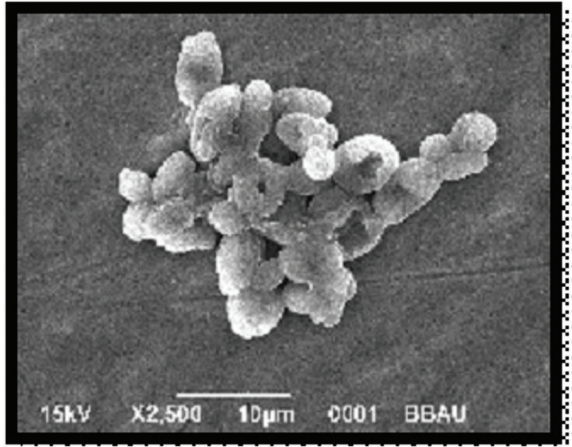

2) Grouped Papain $(30 \mu \mathrm{g} / \mathrm{ml})$ treated cell

Figure 5. SEM images of (A) Control (1) Single Control cell (2) Grouped control cells and (B) Papain $(30 \mu \mathrm{g} / \mathrm{ml})$ (1) Single Papain (30 $\mu \mathrm{g} / \mathrm{ml})$ treated cell (2) Grouped Papain $(30 \mu \mathrm{g} / \mathrm{ml})$ treated S. cerevisiae. 


\section{CONCLUSION}

Papain is a plant proteolytic enzyme used as an anticancerous, anti-tumor, and anti-angiogenic agent. Several mechanisms have been explored till date. The direct toxicity via apoptosis (Akila et al., 2014), cleavage of cell surface protein (Lorusso et al., 1989), and interference in cell signaling pathways have been reported (Jo et al., 2015; Mohr and Desser, 2013). The understanding of the mechanisms is still murky. To explore this problem, we designed the experiment for the nonspecific cytotoxicity of papain in eukaryotic cells ( $S$. cerevisiae) by the MTT and trypan blue assay. Our findings showed no significant effect at different concentrations of papain (1.0, 5.0, 10.0, 20.0, and $30.0 \mu \mathrm{g} / \mathrm{ml}$ ) up to 30 minutes on TPMET and the intracellular $\mathrm{pH}(6.05-6.10)$ of the cells. The SEM images also show similar condition as the control cells. The novelty of this study is the contrasting implications on cell viability observed with results obtained by the two methods as MTT assay and trypan blue exclusion test. The cell viability was about $98 \%-99 \%$ when measured by the trypan blue exclusion method although trypan blue assay is only for the live cells (unstained) and dead cells (stained) depending upon the permeability of plasma membrane (Strober, 2001). According to Seav-Ly Tran et al. (2011), the blue dye-containing cells are metabolically active. However, it cannot be used to distinguish between healthy and live cells by loosening their metabolic functions. The method used for ascertaining cell viability on the basis of cellular function such as enzyme activity, cell membrane permeability, ATP production, movement of ion uptake, and electron extrusion mechanism is the most widely used MTT assay. This method showed a significant gradual decrease in the absorbance by papain in a concentrationdependent manner. It indicated that the papain causes cell toxicity in the cells while cell activity was unaffected as observed through TPMET and intracellular $\mathrm{pH}$. To investigate the toxicity of MTT assay, the papain treated cells were washed two to three times with phosphate buffer $\mathrm{pH} 6.6$ to remove the papain residues from the cells resulting in the resumed activity. To explore the reversal of MTT activity, the effect of the same concentration of papain was used in a cell-free system. The similar gradual decrease in the absorbance of MTT by treatment with papain was observed. The results obtained give a clear indication of the interaction of papain with MTT. To the best of our knowledge, the data reported are novel and will be helpful in checking the reliability of the conclusion drawn in order to serve a larger scientific interest.

\section{ACKNOWLEDGMENTS}

The author would like to thank Amity University, Uttar Pradesh, Lucknow Campus for providing me the facilities. The author would also like to thank Dr. AB Pant, Principal Scientist, Indian Institute of Toxicology Research, Lucknow to help him in the conduct of experiments.

\section{FUNDING}

This work was supported by the Council of Science and Technology, Uttar Pradesh, (Grant No-CST/SERPD/D-278) India.

\section{CONFLICT OF INTEREST}

The authors declare that they have no conflict of interest.

\section{REFERENCES}

Akila M, Sushama A, Ramanathan K. Study on in vitro cytotoxicity of papain against liver cancer cell lines HepG2. Int J Pharmacy Pharm Sci, 2014; 6:160-1.

Berridge MV, Tan SA. Characterization of the cellular reduction of 3-(4, 5-dimethylthiazol-2-yl)-2, 5-diphenyltetrazolium bromide (MTT): subcellular localization, substrate dependence, and involvement of mitochondrial electron transport in MTT reduction. Arch Biochem Biophys, 1993; 303:474-82.

Cookson MR, Mead C, Austwick SM, Pentreath VW. Use of the MTT assay for estimating toxicity in primary astrocyte and C6 glioma cell cultures. Toxicol In Vitro, 1995; 9:39-48.

Diakov TT, Tarsio M, Kane P. Measurement of vacuolar and cytosolic pH in vivo in yeast cell suspensions. J Vis Exp, 2013; 74.

Driska SP, Laudadio RE, Wolfson MR, Shaffer TH. A method for isolating adult and neonatal airway smooth muscle cells and measuring shortening velocity. J Appl Physiol, 1999; 86:427-35.

Fischer ER, Hansen BT, Nair V, Hoyt FH, Dorward DW Scanning electron microscopy. Curr Prot Micro, 2012; 25(1):2B.2.1-47.

Halim YT, Krauss RH, Sun AC, Takei F. Lung natural helper cells are a critical source of Th2 cell-type cytokines in protease allergeninduced airway inflammation. Immunity, 2012; 36:451-63.

Herst PM, Berridge MV. Plasma membrane electron transport: a new target for cancer drug development. Curr Mol Med, 2006; 6:895-904.

Herst PM, Berridge MV. Cell surface oxygen consumption: a major contributor to cellular oxygen consumption in glycolytic cancer cell lines. Biochim Biophys Acta, 2007; 1767:170-7.

Jo HY, Kim Y, Park HW, Moon HY, Bae S, Kim J, Kim DJ, Paek SH. The unreliability of MTT assay in the cytotoxic test of primary cultured glioblastoma cells. Exp Neurobiol, 2015; 24:235-45.

Kaur G, Roberti M, Raul F, Pendurthi U. Suppression of human monocyte tissue factor induction by red wine phenolics and synthetic derivatives of resveratrol. Thromb Res, 2007; 119:247-56.

Kinoshita K, Sato K, Hori KM, Ozaki H, Karaki H. Decrease in activity of smooth muscle L-type $\mathrm{Ca} 2+$ channels and its reversal by NFkappa B inhibitors in Crohn's colitis model. Am J Physiol Gastrointest Liver Physiol, 2003; 285:G483-93.

Lorusso M, Cocco T, Boffoli D, Gatti D, Meinhardt S, Ohnishi T, Papa S. Effect of papain digestion on polypeptide subunits and electrontransfer pathways in mitochondrial b-c1 complex. Eur J Biochem, 1989; 179:535-40.

Ly Tran S, Puhar A, Ngo-Camus M, Ramarao N. Trypan blue dye enters viable cells incubated with the pore- forming toxin HlyII of Bacillus cereus. PLoS One, 2011; 6(9).

Mohr T, Desser L. Plant proteolytic enzyme papain abrogates angiogenic activation of human umbilical vein endothelial cells (HUVEC) in vitro. BMC Complement Altern Med, 2013; 13:231.

Neufeld BH, Tapia JB, Lutzke A, Reynolds MM. Small molecule interferences in resazurin and MTT-based metabolic assays in the absence of cells. Anal Chem, 2018; 90:6867-76.

Revis S, Misra PC. Changes in intracellular redox and energy status during induced transplasma membrane electron transport in Cuscuta protoplasts. Biochem Biophys Res Commun, 1998; 156:940-6.

Savini I, Arnone R, Rossi A, Catani MV, Del PD, Avigliano L. Redox modulation of Ecto-NOX1 in human platelets. Mol Membr Biol, 2010; 27:160-9.

Strober W. Trypan blue exclusion test of cell viability. Curr Protocol Immunol, 22001; 21(1): A.3B.1-A.3B.2.Appendix 3: Appendix 3B.

Tsuge H, Nishimura T, Tada Y, Asao T, Turk D, Turk V, Katunuma N. Inhibition mechanism of cathepsin L-specific inhibitors based on the crystal structure of papain-CLIK148 complex. Biochem Biophys Res Commun, 1999; 266:411-6.

Turk B, Turk V, Turk D. Structural and functional aspects of papain-like cysteine proteinases and their protein inhibitors. BiolChem, 1997; 378:141-50. 
Uhlig H. Industrial enzyme and their application. John Wiley and Sons Inc., New York, NY, 1998.

Vistica DT, Skehan P, Scudiero D, Monks A, Pittman A, Boyd MR. Tetrazolium-based assays for cellular viability: a critical examination of selected parameters affecting formazan production. Cancer Res, 1991; 51:2515-20.

Xiaoling C, Jie W, Yong G, Taicheng Y, Jiang X. Cytotoxicity of chymopapain combined with pingyangmycin on mouse hepatoma cell line hepa-6. Zhong Yao Cai, 2004; 27:267-9.
How to cite this article:

Asif S, Kaur G, Pendurthi U, Awasthi V. Papain-mediated reduction of MTT is an artifact but not an indicator of cell apoptosis in Saccharomyces cerevisiae. J Appl Pharm Sci, 2019; 9(09):119-124. 